\title{
StATOR ReSistanCE Estimation OF AC INDUCTION MOTOR DRIVE
}

\author{
BLAHA, P. \& VACLAVEK, P.
}

Abstract: The aim of this paper is to present the algorithm for online stator resistance estimation of $A C$ induction motor. It can be used along with any control algorithm. It looks for steady state operation when the voltages and currents are harmonic. The stator resistance estimate is realized using $R M S$ values of voltage and current and using actual active power. The main goal of this algorithm is to catch up the slow changes of stator resistance caused by temperature changes. From this point of view it would be suitable for sensorless vector control algorithms of AC induction motors because the good knowledge of this parameter is crucial since it influences steady state error in rotational speed and also the stability of the velocity estimation.

Key words: AC induction motor, identification, stator resistance, sensorless control


Authors' data: Doc. Ph.D. Blaha, P[etr]; Doc. Ph.D. Vaclavek, P[avel], Brno University of Technology, Kolejní 4, 61200 Brno, Czech Republic, blahap@feec.vutbr.cz, vaclavek@feec.vutbr.cz

This Publication has to be referred as: Blaha, P. \& Vaclavek, P. (2007). Stator Resistance Estimation of Ac Induction Motor Drive, Chapter 28 in DAAAM International Scientific Book 2007, B. Katalinic (Ed.), Published by DAAAM International, ISBN 3-901509-60-7, ISSN 1726-9687, Vienna, Austria DOI: $10.2507 /$ daaam.scibook.2007.28 